\title{
Uloga medijske pismenosti u samopredodžbi mladih uvjetovanoj medijskim idealima ljepote
}

Pregledni rad__DOI 10.22522/cmr20190142_ primljeno 19. siječnja 2018.

UDK: 316.774-0.42.3:159.923.2-053.6

$003.02: 316.774$

\section{Tea Stipan}

Bruketa \& Zinic \& Grey, Zagreb, Hrvatska.

E-adresa: tea.stipan@gmail.com

\section{Sažetak}

Mediji danas čine sastavni dio naše svakodnevice i jedan od najvažnijih načina interakcije s okolinom, što je osobito značajno kod mladih osoba, za koje mediji predstavljaju bitan agens socijalizacije i čimbenik koji utječe na oblikovanje identiteta. Sociokulturni standardi ljepote prikazani u medijima mogu imati značajan utjecaj na samopredodžbu vlastitog izgleda kod mladih, kao i na njihove stavove prema poželjnom izgledu. Rezultati dosad provedenih istraživanja pokazuju kako medijski prikazi ideala ljepote bitno utječu na način na koji mlade osobe percipiraju vlastiti izgled. Pregled dostupne literature na temu pokazao je da kratkoročne intervencije medijske pismenosti djeluju u smislu izazivanja medijskog skepticizma i smanjivanja negativnih učinaka, no da stvarne promjene u stavovima zahtijevaju dugotrajnije intervencije. Cilj ovog preglednog rada jest pružiti podrobni uvid u dosadašnja teorijska i istraživačka postignuća iz područja utjecaja medija na samopredodžbu vlastitog izgleda kod mladih te dati smjernice daljnjem proučavanju važnosti medijske pismenosti u regulaciji zadovoljstva vlastitim tijelom.

Ključne riječi: samopredodžba tijela, medijska pismenost, medijski ideali, utjecaj medija, mladi i mediji 


\section{Prikaz idealnog tjelesnog izgledla u medijima}

Mediji čine neizostavan dio ljudske svakodnevice u suvremenom, zapadnom društvu, pa je moguće pretpostaviti da su upravo mediji i način na koji prikazuju idealni tjelesni izgled jedan od čimbenika koji utječu na samopredodžbu vlastitog izgleda. Taj je utjecaj osobito važan za mlade osobe čije tijelo prolazi kroz niz različitih promjena tijekom odrastanja i koji koriste medije na dnevnoj bazi u različite svrhe.

Kroz povijest, koncept ženske ljepote mijenjao se kako bi reflektirao estetske standarde pojedinog vremenskog razdoblja. Kako navode Katzmarzyk i Davis (2001, str. 591), idealna težina i oblik tijela za žene prikazan u medijima promijenio se od zaobljenog početkom 1900-ih godina do sve tanjeg i mršavijeg u posljednjih nekoliko desetljeća. Pomak je osobito vidljiv u posljednjih 20 godina, kada je naglasak na mršavom i idealno građenom ženskom tijelu sve prisutniji u različitim medijskim sadržajima, što su brojna znanstvena istraživanja povezala i s porastom različitih poremećaja hranjenja, poput anoreksije i bulimije (usp. Morris, Katzman, 2003; McKnight, 2003; Harrison, Cantor, 1997; NeumarkSztainer i sur., 2006). Porast količine takvih sadržaja moguće je opisati kao sociokulturnu epidemiju u kojoj ideali koje nameće modna industrija negativno djeluju na adolescente, osobito djevojke, koje idealni tjelesni izgled shvaćaju kao preduvjet uspjeha i ljepote. Budući da se izgled tijela prikazan u medijima predstavlja kao prevladavajuća društvena norma, adolescenti te medijske prikaze mogu shvatiti kao relevantna uporišta za usporedbu.

Iako je većina istraživanja usmjerena na medijske prikaze idealnog ženskog izgleda $\mathrm{i}$ utjecaja koje oni imaju na žene, primjetan je i pomak u načinu na koji mediji prikazuju muško tijelo (usp. Pope i sur., 1999). Glavnu razliku u medijskim prikazima idealnog ženskog i muškog tijela čini veličina i oblik tijela - za žene se uglavnom naglašava ideal mršavosti, dok kod muškaraca prevladava ideal mišićavosti. Idealno muško tijelo kakvo prezentiraju mediji jest vitko i mišićavo (usp. McCabe, Ricciardelli, 2001; Ricciardelli, McCabe, Banfield, 2000), pri čemu se najveći naglasak stavlja na mišićnu masu i opseg tijela, a u skladu s tim se oblikuju i medijski sadržaji upućeni muškarcima koji se odnose na tjelesni izgled. 


\section{Izloženost mladih medijskim idealima ljepote}

Gledajući savršena tijela modela i slavnih osoba koje preplavljuju medije, često se zaboravlja kako to nisu realistične reprezentacije stvarnih ljudi te kako njihov izgled uglavnom odstupa od realnih proporcija tijela u populaciji, ističe Inja Erceg Jugović (2015, str. 20). Zato se izloženost različitim medijskim sadržajima koji prikazuju nerealne tjelesne proporcije često dovodi u vezu s povećanim nezadovoljstvom izgledom, kao i sa željom za preoblikovanjem oblika i veličine tijela.

Kada je riječ o medijskim sadržajima koji imaju poseban utjecaj na sliku tijela, najveći se naglasak stavlja na televizijski program i časopise (Lumb, 2006, str. 4). Strana istraživanja pokazuju kako adolescenti prosječno provedu šest sati dnevno gledajući televiziju (usp. Roberts, Rideout, Foehr, 2005; Roberts i sur., 2004), što se s godinama povećalo i preko sedam sati dnevno (usp. Strasburger, Jordan, Donnerstein, 2010). Valentina Mandarić (2012, str. 132) ističe da mladi za vrijeme osnovne i srednje škole pred školskom pločom provedu 11000 sati, dok 15000 sati provedu pred televizijom, što jasno ukazuje na potrebu za ozbiljnijim bavljenjem ulogom medija u svakodnevnom životu djece i mladih, njihovoj socijalizaciji, odgoju i obrazovanju.

Istraživanje provedeno među hrvatskim adolescentima i adolescenticama pokazalo je da preko 90 posto mladih ima pristup internetu, 80 posto njih sluša glazbu, 54 posto gleda televiziju, a 52 posto filmove (Ilišin i sur., 2013, str. 152). Kada je riječ o izloženosti različitim medijskim oblicima, istraživanje koje je 2014. godine provela Iva Bubalo na uzroku od 280 učenika i učenica završnog razreda šest zagrebačkih srednjih škola pokazalo je da njih 100 posto svakodnevno koristi internet, 99,6 posto sluša glazbu, 89,3 posto gleda televiziju te 52 posto igra video igre. Izloženost televizijskim sadržajima nije manja niti u mlađoj dobnoj skupini - istraživanje provedeno među djecom vrtićkog uzrasta pokazalo je kako djeca svakodnevno gledaju televiziju, dok su njihovi odgovori pokazali potrebu da se identificiraju s likovima koje vide na televizijskom ekranu. „Žele biti poput likova iz crtanih filmova, poput onih likova koje smatraju atraktivnima i za koje osjećaju da su slični njima ili teže biti poput njih. Identificirajući se s likovima ili stvarnim ljudima s ekrana djeca postaju podložnija utjecaju medija“ (Blažević, 2012). Upravo je proces usporedbe mladih s onim što vide na televizijskom ekranu jedan od ključnih načina na koje medijski prikazi utječu na samopercepciju vlastitog izgleda. 
Većina ženskih televizijskih likova je puno mršavija od prosječne žene, pri čemu je svega 10 posto žena koje se pojavljuju na televiziji pretilo (Thompson, Heinberg, 1995, str. 341). Takvi su trendovi još prisutniji u programima namijenjenima mladim djevojkama omiljeni televizijski likovi djevojčica u višim razredima osnovne škole puno su mršaviji od prosječne žene. Istraživanje koje su proveli Smith i sur. (2013) pokazalo je da je dvostruko veća vjerojatnost da će ženski likovi u obiteljskim filmovima, televizijskom programu u udarnom terminu te dječjim televizijskim emisijama imati iznadprosječno uže strukove $u$ usporedbi s muškim likovima.

Rezultati istraživanja kojeg su proveli Amad N. Khan i suradnici (2011) pokazali su kako su pojedinci s visokim stupnjem izloženosti medijskim sadržajima pokazali veću razinu nezadovoljstva tijelom u usporedbi s onima s niskim stupnjem izloženosti medijskim sadržajima. Također, istraživanje koje su proveli Yuko Yamamiya i suradnici (2005) potvrdilo je kako već petominutno izlaganje medijskim idealima ljepote rezultira negativnom slikom tijela u usporedbi s izlaganjem neutralnim prikazima, osobito kod mladih djevojaka $\mathrm{s}$ visokom razinom internalizacije i tendencijom prema socijalnoj usporedbi. Slično su pokazali i rezultati istraživanja kojeg su proveli Shelley Spurr, Lois Berry i Keith D. Walker (2013), koji ističu negativan utjecaj stereotipnih prikaza medijskih modela mršavih žena i vitkih, mišićavih muškaraca, kao tijela nedostižnog za većinu populacije, uključujući i adolescente i adolescentice. Koliko izloženost medijima može utjecati na percipirane standarde ljepote i štetne obrasce ponašanja, pokazuje i istraživanje koje je provela Anne E. Becker (2004) prije i poslije uvođenja zapadnjačkih televizijskih kanala u otočnoj državi Fiji. Tri godine nakon uvođenja zapadnjačke televizije, gotovo 12 posto djevojaka pokazivalo je nezadovoljstvo vlastitim tijelom i znakove poremećaja hranjenja, koji su do tada na tom području bili gotovo nepostojeći.

Uz televiziju, jedan od vodećih medija koji se osobito ističe u prikazivanju idealnog tjelesnog izgleda jesu časopisi, osobito oni namijenjeni ženama. Analiza sadržaja američkih časopisa za žene koju su proveli Amy R. Malkin, Kimberlie Wornian i Joan C. Chrisler (1999) pokazala je kako 94 posto časopisa na naslovnici ima model ili slavnu osobu koja odgovara idealu mršavosti. Time što ne prikazuju veći raspon veličine i oblika tijela, mediji promoviraju ideal mršavosti kao jedini poželjni, čime se ženama nameće sociokulturni ideal ljepote kao jedini društveno prihvatljiv. Medijsko predstavljanje jednostranih slika na račun onih stvarnijih iz širokog spektra tjelesnih oblina potencijalno 
je štetno za mlade jer se na izgled u mladenačko doba stavlja velik naglasak, napominje Metka Kuhar (2005, str. 103).

Sve veća prisutnost i raširenost interneta bitno utječe na način korištenja medija i utjecaja kojeg mediji imaju na adolescente. U posljednjih je deset godina vidljiv porast količine sadržaja koji promoviraju medijske ideale ljepote, često usmjeren na mlade djevojke (usp. Labre, Walsh-Childres, 2003; Slater i sur., 2012). Djevojke u dobi između 12 i 17 godina čine najbrže rastuću skupinu na internetu (Kearney, 2006, str. 243). Istraživanje koje su provele Marika Tiggemann i Amy Slater (2013) na uzorku od 1087 djevojaka pokazalo je da 96 posto djevojaka ima pristup internetu, dok je prosječno korištenje interneta bilo oko dva sata dnevno. Rezultati dobiveni na navedenom uzorku ukazuju na visoku korelaciju izloženosti internetu i internalizacije medijskog ideala, nadgledanja izgleda vlastitog tijela i želje za mršavošću. Podaci također ukazuju na važnost interneta kao dodatnog medija, uz televiziju i modne časopise, koji je povezan uz sliku tijela i zabrinutost zbog vlastitog izgleda.

Pritom je naglasak osobito potrebno staviti na društvene mreže čije korištenje osobito raste među mladim djevojkama, za koje je nezadovoljstvo vlastitim izgledom posebno problematično (Fardouly i sur., 2015). Društvene mreže poput Facebooka, Instagrama, YouTubea i drugih, sadrže vizualni element i podrazumijevanju dijeljenje fotografija koje drugi vide i komentiraju. Suvremene medijske platforme mijenjaju način na koji ljudi internaliziraju ideale ljepote, kontroliraju način na koji ih drugi vide i način na koji dobivaju povratne informacije o vlastitom izgledu (Mills, Shannon, Hogue, 2017). Facebook je trenutno najčešće korištena društvena mreža s više od milijardu korisnika na svijetu (Mills, Shannon, Hogue, 2017, str. 151), zbog čega je istraživački fokus u kontekstu društvenih mreža i nezadovoljstva vlastitim tijelom stavljen upravo na tu društvenu mrežu. Dosad provedena istraživanja (usp. Meier, Gray, 2014; Kim, Chock, 2015; Eckler, Paasche Kalyango, 2016; Puglia, 2016) pokazala su da Facebook predstavlja snažni sociokulturalni čimbenik u stvaranju (negativne) samopredodžbe vlastitog izgleda među mladim djevojkama.

Društvena mreža na kojoj broj korisnika eksponencijalno raste u posljednjih nekoliko godina je Instagram, koji je, u usporedbi s Facebookom, značajno više usmjeren na vizualno predstavljanje. Dominantno vizualna priroda Instagrama dodatno potiče proces socijalne usporedbe izlažući korisnike i korisnice većem broju idealiziranih prikaza i dajući im time više prilika za uspoređivanje s prijateljima i slavnim osobama (Puglia, 2015). Osim toga, 
Instagram kao aplikacija sadrži alate za modifikaciju izgleda (poput različitih filtera), što korisnicima omogućuje da, bez naprednog tehničkog znanja i vještina potrebnih za obradu fotografija, modificiraju svoj izgled. Istraživanje koje su provele Zoe Brown i Marika Tiggemann (2016) na uzroku od 138 studentica preddiplomske razine studija pokazalo je da izloženost fotografijama mršavih modela na Instagramu povećava negativne osjećaje i nezadovoljstvo vlastitim tijelom $u$ usporedbi s neutralnim fotografijama putovanja. Do sličnih su zaključaka došli i Joshua Hendrickse, Laura M.Arpan, Russell B. Clayton i Jessica L. Ridgway (2017), čije je istraživanje pokazalo da je izloženost fotografijama na Instagramu u pozitivnoj korelaciji sa željom za mršavošću i nezadovoljstvom vlastitim tijelom kroz usporedbe vlastitog s izgledom osoba na fotografijama. Autori zaključuju kako Instagram može biti potencijalno štetan za osobe koje se često uspoređuju s drugima. Također, rezultati istraživanja koje su provele Tiggemann i Zaccardo (2015) pokazali su da je izloženost fotografijama na Instagramu koje potiču na vježbanje s ciljem boljeg fizičkog izgleda (fitspiration images) dovodi do većeg nezadovoljstva vlastitim tijelom nego izloženost neutralnim fotografijama.

\subsection{Utjecaj medija na samopredodžbu vlastitog izgleda}

Slika tijela ili predodžba tijela definira se kao „višedimenzionalan konstrukt koji predstavlja subjektivnu reprezentaciju vlastitog tjelesnog izgleda i tjelesnih iskustava te odražava stavove, percepciju, misli i osjećaje osobe vezane uz vlastito tijelo, kako uz cjelokupan izgled, tako i uz specifična područja i dijelove tijela, tjelesne funkcije, snagu i seksualnost “ (Erceg Jugović, 2015, str. 1). Nezadovoljstvo tijelom jedan je od poremećaja slike tijela koji nastaje kao posljedica raskoraka između percipiranog i idealnog tjelesnog izgleda (Erceg Jugović, 2011, str. 4), a može se kretati od blagog nezadovoljstva specifičnim dijelovima tijela, pa sve do ekstremnog nezadovoljstva cjelokupnim izgledom. Slika tijela predstavlja vrlo važan aspekt psihološkog i interpersonalnog razvoja u adolescenciji, osobito kod djevojaka, koje se u tom razdoblju suočavaju s porastom tjelesne mase koja ih udaljava od sociokulturnog ideala ljepote, što rezultira negativnom slikom tijela i nezadovoljstvom vlastitim tijelom (usp. Pokrajac-Bulian i sur., 2005; Erceg Jugović, 2011).

Negativan utjecaj na samopredožbu vlastitog izgleda te veću podložnost poremećajima hranjenja ima i izloženost određenim medijskim sadržajima. Lawrie i suradnici (2006, str. 356) navode kako na petnaestogodišnjakinje najveći pritisak da budu mršave proizvodi ideal vitkosti prikazan u medijima. Utjecaj televizijskog oglašavanja u kojemu su prisutni 
modeli koji prosječno imaju 23 posto manju težinu od tipične žene u populaciji bitno utječe na način na koji mlade djevojke percipiraju vlastiti izgled, što utječe na njihove prehrambene navike i dovodi do razvoja poremećaja hranjenja (Gjylbegaj, 2018). Navedeno potvrđuje i longitudinalno istraživanje na uzroku od 2500 djevojaka osnovnoškolske i srednjoškolske dobi koje je pokazalo dvostruko veću mogućnost razvoja nezdravih načina kontroliranja težine i poremećaja hranjenja kod onih djevojaka koje su češće čitale ženske časopise (van den Berg i sur., 2007). Slično su pokazali i rezultati istraživanja provedenog na uzroku od 2862 djevojke u dobi između 12 i 18 godina - među djevojkama koje su često čitale ženske časopise i slušale radio zabilježena je dvostruko veća mogućnost razvoja poremećaja hranjenja (Martinez-Gonzalez i sur., 2003).

\subsection{Teorijska polazišta utjecaja medija na samopredodžbu mladih}

Potpuno razumijevanje razvoja samopredodžbe vlastitog tjelesnog izgleda nije moguće bez sagledavanja utjecaja šire društvene sredine $u$ kojoj se pojedinac nalazi. Kada se radi o utjecaju medijskih prikaza na tjelesnu samopredodžbu, u literaturi se uglavnom polazi od sociokulturnog modela, koji nudi teorijsko objašnjenje nezadovoljstva tijelom i rastuće stope poremećaja hranjenja, osobito kod djevojaka i žena. Prema sociokulturnom modelu, mediji predstavljaju izvor snažnih poruka o društveno prihvatljivim i neprihvatljivim tjelesnim karakteristikama te utječu na uvjerenja pojedinaca o idealnom tjelesnom izgledu i njihovu procjenu odgovara li njihovo tijelo idealu. Model polazi od pretpostavke da trenutni standardi ljepote $u$ medijima dominantno naglašavaju poželjnost vitkog $i$ mršavog tijela za žene i mišićavog tijela za muškarce. Budući da se pritom ne radi razlika između medijskog prikaza ideala i realnog izgleda tijela prosječne žene i muškarca, medijski se prikazi smatraju realnim reprezentacijama tjelesnog izgleda i prigodnim točkama usporedbe izgleda (Agliata, Tantleff-Dunn, 2004, str. 9).

Među sociokulturne čimbenike koji utječu na nezadovoljstvo tijelom ubrajaju se pritisci od strane roditelja, vršnjaka i medija. Medijski prikazi, osobito oni prikazani u kontekstu reklama za proizvode za smanjivanje težine, promoviraju ideju da su oblik i veličina tijela fleksibilni te da je postizanje ideala vitkosti relativno lako (Monro, Huon, 2005, str. 85). Istraživanje koje su proveli Eric Stice i Kathryn Whitenton (2002) pokazuje da je percipirani sociokulturni pritisak za mršavijim izgledom jači prediktor nezadovoljstva tijelom nego stvarna težina, što implicira da društveni pritisak za mršavim izgledom ima veću ulogu u 
razvoju nezadovoljstva tijelom nego fizičko odstupanje od kulturno definiranog ideala.

Objašnjenje za razlike $u$ (ne)zadovoljstvu vlastitim izgledom moguće je pronaći u procesu socijalne usporedbe. Prema teoriji socijalne usporedbe, koju je originalno razvio Leon Festinger (1954), ljudi imaju nagon za evaluacijom vlastitih mišljenja i sposobnosti, a najučinkovitiji način za evaluaciju jest usporedba vlastitih mišljenja i sposobnosti s onima drugih ljudi, i to onih koji su nam slični. Od onda je teorija doživjela određene preinake pa tako referentne točke za usporedbu nisu više samo mišljenja i sposobnosti, već $i$ druge motivacije, poput tjelesnog izgleda i navika hranjenja. Rezultat procesa socijalne usporedbe ovisit će o smjeru usporedbe, odnosno, radi li se o silaznoj ili uzlaznoj usporedbi. O silaznoj usporedbi je riječ ako se pojedinac uspoređuje s nekim tko mu je inferioran ili se nalazi u gorem položaju, pa takve usporedbe rezultiraju poboljšanjem raspoloženja i samopoštovanja. S druge strane, uzlazne usporedbe se odnose na uspoređivanje sebe $\mathrm{s}$ osobom koja je superiorna u nekoj dimenziji, što dovodi do smanjenog samopoštovanja i zadovoljstva sobom (Lumb, 2006, str. 6). Mediji i vršnjaci najčešće su mete usporedbe koje se razlikuju s obzirom na dimenziju sličnosti. Medijski prikazi obično predstavljaju nerealne prikaze tjelesnog izgleda koji se bitno odmiču od prosječne žene ili muškarca, dok se vršnjaci, s druge strane, češće gledaju kao sličniji pojedincu, što potvrđuju i rezultati studije koju su proveli Danielle R. Ridolfi i suradnici (2011).

Bitna razlika koju je potrebno napraviti kada se radi o utjecaju medija na samopredodžbu izgleda jest razina svjesnosti pojedinca o sociokulturnim normama i razina internalizacije sociokulturnih normi - svjesnost se odnosi na znanje da ideali postoje, a internalizacija na usvajanje ili prihvaćanje tih ideala (Balcetis i sur., 2013, str. 101). Internalizacija ideala vitkosti prepoznata je kao ključna komponenta u razvoju nezadovoljstva tijelom, a često se javlja prije adolescencije i povezuje se uz motivaciju za provođenje dijete $u$ predadolescentnom razdoblju, navode Lawrie i suradnici (2006, str. 356). Neka istraživanja pokazuju kako se internalizacija medijskog ideala vitkosti javlja već kod djevojčica predškolske dobi. Istraživanje koje su proveli Jennifer A. Harriger i suradnici (2010) pokazalo je kako djevojčice između treće i pete godine života povezuju više negativnih atributa s debelim prikazima i više pozitivnih s vitkim prikazima ženskog tijela. Autori zaključuju kako djevojčice nisu imune na poruke o idealnom tjelesnom izgledu koje mediji odašilju te da je moguće da je kombinacija poruka usmjerenih protiv debljine i pritisak za postizanjem nerealnih standarda ljepote povezan s razvojem stereotipa o tjelesnom izgledu i internalizacijom medijskih ideala vitkosti kod vrlo mladih djevojčica. 


\subsection{Rodne razlike u utjecaju medijskih ideala na samopredodžbu vlastitog izgleda}

Većina istraživanja koja se bave odnosom medija i samopredodžbe vlastitog izgleda provodi se na uzorku ženske populacije (usp. Van Vonderen, Kinnaly, 2012; Anschutz i sur., 2009; Daniels, 2009; Stice, Whitenton, 2002; Tiggemann, Pickering, 1996), što nije začuđujuće, $s$ obzirom da je kulturalni pritisak za dostizanjem nametnutih sociokulturnih standarda na žene daleko veći u odnosu na muškarce.

Istraživanja pokazuju da se nezadovoljstvo vlastitim izgledom kod djevojčica javlja već između osme i desete godine života te da raste s godinama, u skladu s tjelesnim promjenama koje djevojke doživljavaju tijekom odrastanja (Lumb, 2006, str. 10). S ulaskom u pubertet, zabrinutost oko vlastitog izgleda postaje sve učestalija - do srednje adolescencije, djevojkama postaje uobičajeno osjećati nezadovoljstvo težinom, strah od daljnjeg debljanja i zaokupljenost pokušajima mršavljenja (Striegel-Moore, Franko, 2002, str. 184). Istraživanje koje je provela Erceg Jugović (2015) pokazalo je kako su djevojke, u odnosu na mladiće, nezadovoljnije svim aspektima svog tjelesnog izgleda osim visinom, za koju nisu pronađene spolne razlike. To ne iznenađuje ako se uzme u obzir da fizičke promjene koje prate odrastanje odmiču djevojke od sociokulturnog ideala ženskog izgleda, dok mladiće približavaju idealu muškog izgleda (Labre, Walsh-Childers, 2003, str. 380).

Dvije meta-analize koje su proveli Lisa M. Groesz, Michael P. Levine i Sarah K. Murnen (2002) te Shelly Grabe, Janet S. Hyde i Monique L. Ward (2008) pokazuju kako izlaganje medijskim idealima vitkosti neposredno dovodi do nezadovoljstva tijelom kod žena. Korelacijske su studije povezale izloženost medijima s negativnim osjećajima prema vlastitom tijelu, dok se eksperimentalnim studijama, koje ukazuju da trenutne psihološke učinke medijskih prikaza na sliku tijela, potvrdilo veće nezadovoljstvo tijelom kod žena koje su bile izložene idealima vitkosti u usporedbi s onima koje nisu (Ashikali, Dittmar, 2012, str. 515). Rezultati korelacijskih studija pokazuju kako konzumacija medijskih ideala vitkosti ide ruku pod ruku s negativnom slikom tijela i nezadovoljstvom vlastitim tijelom. Za razliku od eksperimentalnih uvjeta u kojima se obično provjerava utjecaj medijskih sadržaja na percepciju vlastitog izgleda, izloženost medijima u stvarnom svijetu je daleko veća (Tiggemann, 2006, str. 537). Iako eksperimentalno izlaganje medijskim idealima nije ni približno masovnoj izloženosti koja ima kumulativan učinak kroz godine, snaga ove metode leži u prokazivanju kauzalne povezanosti između medijskih manipulacija i slike tijela kod žena (Grabe, Ward, Hyde, 2008, str. 461). 
Iako se općenito smatra da muškarci, u usporedbi sa ženama, vlastitom izgledu pridaju puno manje pozornosti, neka istraživanja u posljednjih desetak godina ukazuju na čimbenike koji bi mogli biti odgovorni za tu navodnu razliku. Duane A. Hargreaves i Marika Tiggemann (2006) proveli su istraživanje s ciljem razumijevanja čimbenika koji utječu na sliku tijela kod adolescenata, a rezultati su pokazali kako mladići ne žele razgovarati o nezadovoljstvu tijelom jer se to ne smatra „muškim pitanjem“. Navodna nezainteresiranost mladića za sliku tijela nije u skladu s njihovim ponašanjem, koje pokazuje da su mladići zabrinuti za izgled vlastitog tijela i više nego što žele priznati. Zbog toga je u radu s muškarcima i mladićima, neovisno o tome radi li se izravno o nezadovoljstvu tijelom ili posrednim načinima pristupanja tom pitanju, potrebno uzeti u obzir i njihovu nevoljkost da razgovaraju o tom pitanju (Grogan, 2006, str. 526).

$\mathrm{U}$ posljednjih je nekoliko godina vidljiv porast idealiziranih prikaza muškog tijela $\mathrm{u}$ medijima, osobito u časopisima namijenjenim muškarcima i sadržajima koji se tiču sporta, zdravlja i vježbanja (Chia, Wen, 2010, str. 542). Isto kao što su žene osjetljive na propagiranje kulture mršavosti u medijima, tako i muškarci reagiraju na kulturu mišićavosti. PokrajacBulian i suradnici (2005, str. 59) navode da zabrinutost i nezadovoljstvo tjelesnim izgledom nisu isključivo odlike žena jer sociokulturna očekivanja o idealnom tjelesnom izgledu utječu i na muškarce, no manifestiraju se na drugačije načine - kod žena se radi o gubitku tjelesne težine, dok se kod muškaraca očituje u gubljenju i dobivanju na težini, posebice mišićnoj masi.

U usporedbi sa ženama, postoji relativno malo istraživanja koja se bave mogućim utjecajem medijskih prikaza idealnog muškog tijela na zdravlje i samopredodžbu muškaraca. Dok žene teže vitkom i mršavom tijelu, muškarci u prosjeku žele povećati mišićnu masu (usp. Spurr, Berry, Walker, 2013; McCabe, Ricciardelli, 2001) zbog čega se podaci dobiveni na uzorku žena i djevojaka ne mogu generalizirati na muškarce i mladiće, pa je potrebno veći naglasak staviti na istraživanje zadovoljstva tijelom kod muškaraca.

\subsection{Mogući pozitivni utjecaji medija na samopredodžbu}

Iako se u literaturi uglavnom polazi od negativnog utjecaja medija na zadovoljstvo izgledom, a većina istraživanja također upućuje na negativne posljedice izlaganja medijskim sadržajima, postoje i neke iznimke koje ukazuju na moguće pozitivne utjecaje medija na samopredodžbu. S obzirom na količinu medijskih sadržaja usmjerenih na žene i djevojke koji se usko fokusiraju na fizički izgled, korisno je znati kakvi bi medijski sadržaji mogli potaknuti pozitivne promjene. 
Istraživanje koje su provele Phillippa C. Diedrichs i Christina Lee (2011) pokazalo je kako je za žene s prosječnim i visokim stupnjem internalizacije sociokulturnih ideala ljepote, izlaganje ženskim modelima prosječne težine i veličine tijela povezano sa znatno pozitivnijom slikom tijela $\mathrm{u}$ usporedbi s izlaganjem vitkim modelima ili bez modela. Također, za muškarce s visokim stupnjem internalizacije ideala muškog izgleda, izlaganje modelima prosječne veličine tijela bilo je povezano s pozitivnijom slikom tijela $\mathrm{u}$ usporedbi s izlaganjem vitkim modelima. Ovi rezultati ukazuju na to da modeli prosječne veličine i težine tijela mogu promovirati pozitivnu sliku tijela i svejedno biti privlačni konzumentima.

Međutim, s obzirom na nedostatak promjena u industriji koja se bavi različitim aspektima izgleda na kojima se temelje medijski sadržaji namijenjeni mladim djevojkama i ženama, ali i muškarcima, potrebno je pronaći način kako ih osposobiti da kritički pristupaju sadržaju kojem su izložene i kojeg konzumiraju. U tom se pogledu medijska pismenost nameće kao ključan koncept $\mathrm{u}$ razvoju kompetencija potrebnih za sveobuhvatno razumijevanje medija i medijskih sadržaja.

\section{Medijska pismenost}

Novi su mediji promijenili način na koji je svijet povezan i međusobno komunicira, a internetski prostor postaje sve složeniji i dinamičniji u usporedbi s tradicionalnom medijskom sferom. Eksplozija internetskih stranica za dijeljenje sadržaja, poput Facebooka, YouTubea i Twittera, i njihova popularnost, potvrđuju rastuću važnost u životima današnje mladeži (Miočić, Perinić, 2014, str. 232). Danas, kada je većina svjetske populacije pismena u klasičnom smislu i kada sve više raste svijest o utjecaju i važnosti moderne informacijsko-komunikacijske tehnologije, potrebno je uzeti u obzir nove vrste pismenosti nužne za sudjelovanje u suvremenom društvu, među kojima se osobito ističe medijska pismenost.

Iako se u literaturi mogu pronaći brojne definicije medijske pismenosti, najčešće citirana jest ona prema kojoj se medijska pismenost definira kao sposobnost pristupa, analize, vrednovanja i stvaranja medijskih sadržaja (Aufderheide, 1993). Medijska pismenost pritom uključuje razumijevanje različitih vrsta medija, od dnevnih novina do interneta, i svrhe u koje pojedini mediji mogu biti korišteni (Ferguson, 2005, str. 12). Osim činjenice da mladi 
danas sve više vremena provode koristeći medije, potrebu za medijskim opismenjavanjem opravdava i važnost koju informacija kao takva ima u razvoju demokracije, društvene participacije i aktivnog građanstva (Koltay, 2011, str. 212).

Najviše istraživanja vezanih uz medijsku pismenost usredotočuje se na audiovizualne medije, budući da oni čine neizostavan dio svakodnevnih života ljudi u današnjem društvu, no s obzirom na sve veći prodor informacijsko-komunikacijskih tehnologija, pozornost je potrebno usmjeriti i prema tim medijima i medijskim sadržajima. S pojavom novih medijskih tehnologija, tradicionalna medijska pismenost više nije dovoljna za potpuno sudjelovanje i razumijevanje novih medijskih okruženja. Internet postaje sve važniji dio svakodnevnog života mladih ljudi koji uz pomoć interneta formiraju svoj identitet, društvene veze s vršnjacima i vlastiti prostor (Pfaff-Rüdiger, Riesmeyer, Kümpel, 2012, str. 43). Zbog toga Miočić i Perinić (2014, str. 234) navode pojam nove medijske pismenosti koja je vezana uz sposobnost uporabe računala, društvenih medija i interneta. Više nije riječ samo o mogućnosti pristupa sadržaju, već i o prepoznavanju njegovih mogućnosti i ograničenja.

Istraživanje o medijskoj pismenosti mladih i uporabi medija koje su proveli Filip Gospodnetić i Domagoj Morić (2014) pokazalo je da mladi internet i društvene mreže koriste gotovo svakodnevno te ih smatraju najkorisnijim medijima današnjice, no i dalje su prema njima nedovoljno kritični. Upravo zato, medijsko opismenjavanje mladih prije svega bi se trebalo usmjeriti na izgradnju vještina poput kritičkog mišljenja, tumačenja i sinteze informacija (Lasić-Lazić, Špiranec, Banek Zorica, 2012).

Tome u prilog ide istraživanje koje je provela Lana Ciboci (2018) među učenicima osmih razreda zagrebačkih osnovnih škola, koje je pokazalo da „iako se većina zagrebačkih učenika, kad je u pitanju pristup medijima i znanje o medijima, nalazi na naprednoj razini, rezultati istraživanja pokazali su da većina učenika osmih razreda, na kraju obveznog medijskog obrazovanja, posjeduje srednju razinu kritičkog vrednovanja i stvaranja medijskih sadržaja“" (Ciboci, 2018, str. 39). Upravo je zato nužno u programe medijske pismenosti uključiti alate i tehnike koji će mladima dati potrebna znanja i vještine za suvereno korištenje medija i stvaranje medijskih sadržaja, ali i ojačati ulogu medijske pismenosti u obrazovanju, budući da dio mladih nije niti čuo za pojmove medijskog odgoja, medijskih kompetencija i medijske pismenosti (usp. Labaš, Marinčić, 2018). 


\subsection{Značenje medijske pismenosti u obrazovanju}

U kontekstu današnjeg medijski zasićenog društva, bilo bi vrlo neodgovorno ignorirati činjenicu da internet i ostali masovni mediji igraju veliku ulogu u socijalizaciji i obrazovanju mladih, zbog čega je nužno osigurati obrazovne programe koji uključuju medijsku pismenost i omogućuju mladima razumijevanje prirode i učinaka medijske kulture (Kellner, Share, 2005, str. 371). Ako uzmemo u obzir obrazovni potencijal suvremenih medija, pitanje odnosa između medija i odgoja postaje sve aktualnije. Medijska pismenost omogućuje mladima da inteligentno koriste medije, vrednuju medijske sadržaje i kritički razmatraju što im mediji poručuju. Kako bi pripremili današnje mlade ljude za život $u$ 21. stoljeću, nastavnici se moraju početi baviti kompleksnim, tehnološki razvijenim medijskim okruženjem koje je dio svakodnevnog života mladih osoba. To uključuje razumijevanje toga što mediji mogu učiniti mladim ljudima, zajedno s razumijevanjem toga što mladi rade s medijima (Considine, Horton, Moorman, 2009, str. 472). Osim akademskih nastojanja, nastavnici, roditelji, medijski djelatnici i druge interesne skupine $\mathrm{u}$ medijskoj pismenosti imaju ulogu i odgovornost u ostvarenju uspješnog medijskog obrazovanja (Bilici, 2014, str. 71). Programi medijske pismenosti mogu biti uspješni jedino ako sve interesne skupine pravilno razumiju prirodu medijske pismenosti, aktivno je podupiru i implementiraju u školski program. U medijskom obrazovanju, neformalno učenje jednako je važno kao i ono formalno, zbog čega bi programi medijske pismenosti trebali integrirati i formalno i neformalno učenje. Neformalno je učenje učinkovito jer je personalizirano, prilagođeno pojedincu i vremenski fleksibilno, što je osobito bitno za mlade osobe (Bilici, 2014, str. 72). Rezultati istraživanja koje su provele Violeta Vidaček Hainš, Valentina Kirinić i Ksenija Pletenac (2007) pokazali su da je razina razvoja medijske pismenosti kod djece predškolske dobi pozitivno povezana sa sveukupnom razinom razvoja informacijske pismenosti što, zajedno s visokim stupnjem izloženosti medijima, poziva na potrebu za izradom boljih obrazovnih sadržaja u predškolskom kurikulumu, koji bi uključivali i medijsko opismenjavanje djece.

U odgojno-obrazovnom sustavu u Hrvatskoj ne postoji sustavno medijsko obrazovanje, a medijsko opismenjavanje ovisi o angažiranosti i motiviranosti nastavnika (Blažević, 2012, str. 482), s obzirom na to da u nastavnom planu i programu ne postoji raspodjela broja sati namijenjenih medijskoj pismenosti (Miliša, Šaravanja, 2011, str. 191). Medijski je odgoj u Hrvatskoj tek naznačen, a provodi se u okviru nastave hrvatskog jezika u osnovnim školama, gdje čini jedno od četiri nastavna područja pod nazivom medijska kultura. Istraživanje 
koje su proveli Zlatko Miliša i Marija Šaravanja (2011) o zastupljenosti medijskih sadržaja u čitankama hrvatskog jezika u osnovnim školama pokazalo je kako su tekstovi koji spadaju pod medijsku kulturu uglavnom usmjereni na filmsku i kazališnu umjetnost, dok su tekstovi koji kod djece razvijaju kritičko mišljenje i medijske kompetencije prisutni u rijetkim slučajevima. Dok medijska pismenost ne dobije značajniju ulogu u formalnom obrazovanju, potrebno je pokazati inicijativu za razvijanjem neformalnih organizacija čiji medijski stručnjaci mogu omogućiti znanje potrebno za lakše snalaženje u medijski zasićenom društvu.

\subsection{Intervencije medijske pismenosti}

U literaturi se polazi od pretpostavke da masovni mediji neprestano proizvode različite direktne i indirektne utjecaje na pojedince i društvo te da ti utjecaji izazivaju kognitivne, bihevioralne, psihološke i druge učinke tijekom izlaganja medijskim sadržajima ili se tijekom vremena nakupljaju i oblikuju znanja, vjerovanja i navike (Potter, 2010, str. 684). Za mnoge od tih učinaka se pretpostavlja da su negativni te da je moguće konstruirati intervencije kojima se pojedincima pomaže da izbjegnu navedene negativne utjecaje u svakodnevnom životu. Intervencija se definira kao specifična strategija napravljena kako bi pomogla pojedincima, osobito djeci i mladima, da se zaštite od potencijalno štetnih učinaka izloženosti masovnim medijima (Potter, 2010, str. 684). U tom smislu, cilj intervencije medijske pismenosti jest ili zaštititi ljude od pojave takvih učinaka ili umanjiti postojeće negativne utjecaje. Intervencije medijske pismenosti imaju različit učinak na dva tipa ishoda: znanje o pojedinim aspektima medija i medijskih poruka i ishodi vezani za promjenu ponašanja. Lakše je promijeniti razinu znanja o pojedinim medijskim aspektima, nego promijeniti ponašanje vezano uz konkretno korištenje medija (Žuran, Ivanišin, 2013, str. 9). Zbog toga je teško prepoznati razliku između postizanja medijskih kompetencija i njihove aktualizacije, budući da pojedinci mogu imati visoko razvijenu medijsku pismenost, ali ne koristiti to znanje u svakodnevnom životu. Iako znanje ne mora nužno odmah dovesti do promjena u ponašanju, ono može proizvesti zaštitu protiv vanjskih pritisaka u nekom kasnijem periodu i pružiti temelje za evaluaciju novih situacija (Golan, Hagay, Tamir, 2014, str. 7).

U kontekstu medijske pismenosti, moguće je razlikovati prirodne intervencije, razvijene od strane roditelja u svakodnevnom životu, i konstruirane intervencije, razvijene od strane stručnjaka i testirane kako bi im se procijenila učinkovitost, pri čemu su obje uglavnom 
usmjerene na djecu i mlade osobe. Pritom je konstruirane intervencije medijske pismenosti moguće podijeliti u nekoliko kategorija ovisno o medijskom sadržaju, pa se razlikuju intervencije vezane uz nasilje u medijima, seksualne sadržaje, zdravstvene teme (pušenje, poremećaji hranjenja), stereotipe i sadržaje koji izazivaju strah (Potter, 2010, str. 688).

\subsubsection{Intervencija medijske pismenosti u reguliranju nezadovoljstva vlastitim tijelom}

Kada se radi o intervencijama medijske pismenosti usmjerenima na nezadovoljstvo vlastitim tijelom kod mladih osoba, polazi se od pretpostavke da intervencije mogu pomoći mladim ljudima da prepoznaju kako im mediji nastoje prodati određene proizvode i način ponašanja koji za njih ne moraju uvijek biti poželjni (Martens, 2010, str. 7). Intervencije medijske pismenosti uključuju kritičku analizu sadržaja medijskih poruka kojima se nastoji smanjiti ili spriječiti internalizacija medijskih ideala i proces socijalne usporedbe (Yamamiya i sur., 2005 , str. 75). S obzirom na to da brojna istraživanja ukazuju na utjecaj kojeg mediji imaju na samopredodžbu vlastitog izgleda, neki autori govore o potencijalu programa medijske pismenosti u školama koji bi potaknuli mlade, osobito djevojke, da kritički razmišljaju o idealu tjelesnog izgleda u medijima i odbiju negativne posljedice koje proizlaze iz izloženosti medijskim idealima.

Kada se mlade educira o medijima i uči da kritički sagledavaju medijske prikaze izgleda, oni manje internaliziraju medijske ideale ljepote, a računalno modificirane prikaze doživljavaju manje realno (Kiefner-Burmeister, 2014, str. 7). Programi medijske pismenosti koji se usredotočuju na razotkrivanje računalno modificiranih prikaza u medijima pokazuju se kao uspješni u smanjivanju nezadovoljstva tijelom kod djevojaka nakon izlaganja modificiranim prikazima žena u medijima. Čak i kratkoročne intervencije ovog tipa pokazuju rezultate u smanjivanju zabrinutosti vlastitom težinom i socijalnom usporedbom s modelima (Kiefner-Burmeister, 2014, str. 7). Istraživanja sugeriraju da su intervencije usredotočene na razotkrivanje modificiranih prikaza uspješne jer pojedinci svjesno usmjeravaju pozornost na digitalne manipulacije na fotografijama, što se pokazuje kao bitna komponenta $\mathrm{u}$ intervencijama medijske pismenosti. Ako intervencije medijske pismenosti mogu umanjiti vjerodostojnost medijskih poruka o poželjnom ženskom izgledu i povećati opseg do kojeg žene takve prikaze smatraju nerealnima, takva bi vrsta promjene mogla prekinuti proces socijalne usporedbe koji se smatra jednim od ključnih medijatora u povezanosti izloženosti medijskim idealima i nezadovoljstva vlastitim tijelom (Engeln-Maddox, Miller, 2008, str. 160). 
S obzirom na to da su mladi svakodnevno bombardirani medijskim sadržajima koji prikazuju ideale tjelesnog izgleda nedostižne za većinu, ponekad kratkoročne intervencije medijske pismenosti ne moraju nužno rezultirati poželjnim ishodom, odnosno, smanjenjem nezadovoljstva vlastitim tijelom. Kratkoročne intervencije medijske pismenosti pokazuju neke rezultate $u$ poboljšavanju slike tijela i internalizaciji medijskih ideala, ali teže dovode do stvarne promjene u ponašanju (Yager, O’Dea, 2008, str. 184). Zbog toga neki predlažu da je dužina intervencije, radije nego njen sadržaj, važnija za postizanje željenih rezultata. Rebecca Watson i Lisa M. Vaughn (2006) provele su istraživanje s ciljem određivanja učinaka kratkoročne i dugoročne intervencije medijske pismenosti sličnog sadržaja na nezadovoljstvo tijelom, svjesnost o postojanju sociokulturnih standarda ljepote i internalizacije istih. Rezultati su pokazali da i kratkoročna i dugoročna intervencija imaju potencijal smanjiti internalizaciju sociokulturnih ideala, a da je dugoročna intervencija medijske pismenosti učinkovitija u smanjivanju nezadovoljstva vlastitim tijelom u usporedbi s kratkoročnom intervencijom, što su potvrdila i druga istraživanja (usp. Stice, Shaw, 2004; Lumb, 2006).

Dok pojedinci kroz obrazovne sadržaje mogu individualno biti potaknuti da kritički sagledavaju medijske poruke o idealnom tjelesnom izgledu, zbog snažnog utjecaja vršnjaka u tom životnom periodu, takvi edukativni programi moraju uključiti adolescente i adolescentice u aktivnu, refleksivnu interakciju s njihovim vršnjacima. U suprotnom bi mladi mogli biti svjesni opasnosti poruka o medijskom idealu ljepote, no svejedno odbijati djelovati u skladu sa znanjem, ako smatraju da i njihovi vršnjaci nisu čuli, razumjeli i prihvatili takve poruke (Spurr i sur., 2013, str. 33). Zbog toga programi medijske pismenosti, da bi bili uspješni, moraju uključiti mlade i njihove vršnjake u raspravu o medijski posredovanim porukama.

\section{Prema zalključku}

Mediji čine sastavni dio naše svakodnevice i jedan od najvažnijih načina interakcije s okolinom. Osim toga, utječu i na oblikovanje naših stavova o sebi samima i svijetu oko sebe, što je osobito značajno kod mladih osoba, za koje mediji predstavljaju bitan agens socijalizacije i čimbenik koji utječe na formiranje identiteta. Sociokulturni standardi ljepote prikazani u medijima mogu imati značajan utjecaj na samopredodžbu vlastitog izgleda kod mladih ljudi, kao i na njihove stavove prema poželjnom izgledu i (ne)zdravim načinima postizanja istog. Mediji ne samo da omogućuju prijenos kulturoloških ideala ljepote i poželjnog tjelesnog izgleda, već ih i sami stvaraju. 
Medijski prikazi tjelesnih ideala za žene i muškarce mijenjao se tijekom stoljeća, $\mathrm{s}$ tendencijom sve mršavijeg izgleda za žene i mišićave tjelesne konstitucije za muškarce. Socijalna poželjnost mršavog ženskog tijela bujnog poprsja te mišićavog muškog tijela širokih ramena predstavlja ideal ženskog odnosno muškog tjelesnog izgleda današnjice, ističe Inja Erceg Jugović (2015, str. 19). Budući da se izgled tijela prikazan u medijima predstavlja kao prevladavajuća društvena norma, adolescenti te medijske prikaze mogu shvatiti kao relevantna uporišta za usporedbu. Upravo se proces socijalne usporedbe $\mathrm{s}$ idealiziranim prikazima tjelesnog izgleda ističe kao jedan od glavnih katalizatora nezadovoljstva vlastitim tijelom - mediji utječu na mišljenja djevojaka i mladića o vlastitom tijelu tako da ona postaju referentne točke za uglavnom negativne usporedbe.

Pregled teorijskih radova i dosad provedenih istraživanja pokazuje su mladi svakodnevno izloženi različitim medijskim sadržajima i oblicima, a medijski ideali ljepote prikazani u različitim medijskim sadržajima bitno utječu na samopredodžbu vlastitog izgleda kod mladih osoba. Pritom se poseban naglasak stavlja na televizijski program u kojem je, kako ističu Thompson i Heinberg (1995), većina ženskih televizijskih likova puno mršavija od prosječne žene. Osim što se identifikacija s medijskim modelima navodi kao važan faktor $u$ prenošenju normi i vrijednosti o izgledu, većina televizijskih programa iziskuje i emocionalno poistovjećivanje, što dodatno osnažuje identifikaciju s likovima (Anschutz i sur., 2009, str. 1046) i potiče proces socijalne usporedbe.

Osim masovnih medija, važnu ulogu u samopredodžbi izgleda danas imaju novi mediji, osobito društvene mreže. Novi su mediji promijenili način na koji pristupamo medijima i konzumiramo medijske sadržaje. Vizualne platforme koje se primarno temelje na dijeljenju fotografija, poput Instagrama, potencijalno imaju veći utjecaj na mlade koji su skloni negativnim socijalnim usporedbama od platformi koje veći naglasak stavljaju na tekstualni sadržaj. Upravo zato, u budućim je istraživanjima utjecaja društvenih mreža na samopredodžbu vlastitog izgleda potrebno razlučiti pojedine društvene mreže kako bi se dobio bolji uvid u povezanost izloženosti i konzumacije društvenih mreža i utjecaja istih na (ne)zadovoljstvo vlastitim izgledom.

Iako su potaknuli ideju o aktivnom sudjelovanju pojedinaca u stvaranju medijskih sadržaja, novi su mediji istovremeno promijenili društvene prakse i pridonijeli smanjivanju kritičkih stavova prema medijima (Žuran, Ivanišin, 2013, str. 10). Kao jedan od najboljih načina suočavanja s tim problemima nameću se medijski odgoj i medijsko opismenjavanje, $s$ ciljem osposobljavanja pojedinaca da kritički i analitički pristupaju medijskim sadržajima. 
Medijska je pismenost danas koncept koji se često pojavljuje, osobito u medijskoj regulaciji gdje obrazovni programi medijske pismenosti nastoje zaštititi mlade u sve složenijem medijskom okruženju. Međutim, medijska pismenost nema samo obrambenu svrhu, $u$ kontekstu zaštite pojedinaca od štetnih utjecaja medija, već i proaktivnu svrhu koja je jednako važna, a tiče se promicanja sposobnosti kritičkog mišljenja i razumijevanja složenih pitanja suvremenog, medijski zasićenog, društva.

Budući da mediji proizvode različite izravne i neizravne utjecaje na pojedince koji potom izazivaju kognitivne, bihevioralne, psihološke i druge učinke, potrebno je pronaći načine kako kontrolirati i ublažiti (negative) posljedice izlaganja medijskim sadržajima. Jedan od načina su različiti oblici intervencija kojima se potiče analiza i kritičko sagledavanje poruka koje mediji odašilju. Intervencije medijske pismenosti u kontekstu samopredodžbe vlastitog izgleda pokazuju se kao koristan alat $\mathrm{u}$ regulaciji stupnja zadovoljstva vlastitim izgledom kod adolescenata i poticanju na evaluaciju medijskih sadržaja kojima su izloženi. Rezultati istraživanja provedenih na ovu temu pokazuju kako su dugoročne intervencije učinkovitije u promjeni stavova i ponašanja mladih osoba od onih kratkoročnih, što pokazuje potencijal medijske pismenosti $\mathrm{u}$ regulaciji zadovoljstva vlastitim tijelom i daje smjernice za razvoj i implementaciju iste $\mathrm{u}$ formalnom (i neformalnom) obrazovnom sustavu.

\section{Popis literature}

- Agliata, D., Tantleff-Dunn, S. (2004). The Impact of Media Exposure on Male's Body Image. Journal of Social and Clinical Psychology, 23 (1), 7-22.

- Anschutz, D. J., Engels, R., Van Leeuwe, J., Van Strien, T. (2009). Watching Your Weight? The Relations Between Watching Soaps and Music Television and Body Dissatisfaction and Restrained Eating in Young Girls. Psychology and Health, 24 (9), $1035-1050$.

- Ashikali, E., Dittmar, H. (2012). The Effect of Priming Materialism on Women’s Responses to Thin-Ideal Media. British Journal of Social Psychology, 51 (4), 514-533.

- Aufderheide, P. (1993). Media Literacy: A Report of the National Leadership Conference on Media Literacy. Queenstown, MA: The Aspen Institute.

- Balcetis, E., Cole, S., Chelberg, M. B., Alicke, M. (2013). Searching Out the Ideal: Awareness of Ideal Body Standards Predicts Lower Global Self-esteem in Women. Self and Identity, 12 (1), 99-113.

- Becker, A. E. (2004). Television, Disordered Eating, and Young Women in Fiji: Negotiating Body Image and Identity during Rapid Social Change. Culture, Medicine and Psychiatry, 28 (4), 533-559.

- Bilici, E. I. (2014). Competition vs. Collaboration: A Study on Promoting Children's, Parental and Teachers' Collaborative Roles in Twenty First Century Digital and Media Literacy Education. Medijska istraživanja, 20 (2), 68-84.

- Blažević, N. (2012). Djeca i mediji - odgoj na televizijski način. Nova prisutnost, 10 (3), 479-493.

- Brown, Z., Tiggemann, M. (2016). Attractive celebrity and peer images on Instagram: Effect on women's mood and body image. Body Image, 19, 37-43.

- Bubalo, I. (2014). Izloženost medijima, stav prema rodnim ulogama i percepcija ženske medijske reprezentacije kod starijih adolescenata (diplomski rad). Zagreb: Filozofski fakultet.

- Chia, S. C., Wen, N. (2010). College Men's Third-Person Perceptions about Idealized Body Image and Consequent Behaviour. Sex Roles, 63 (7-8), 542-555.

- Ciboci, L. (2018). Medijska pismenost učenika osmih razreda u Zagrebu. Medijske studije, 9 (17), 23-46. 
- Considine, D., Horton, J., Moorman, G. (2009). Teaching and Reading the Millennial Generation Through Media Literacy. Journal of Adolescent and Adult Literacy, 52 (6), 471-481.

- Daniels, E. A., (2009). Sex Objects, Athletes and Sexy Athletes: How Media Representations of Women Athletes Can Impact Adolescent Girls and College Women. Journal of Adolescent Research, 24 (1), 399-422.

- Diedrichs, P. C., Lee, C. (2011). Waif goodbye! Average-size Female Models promote positive body image and appeal to consumers. Psychology and Health, 26 (10), 1273-1291.

- Eckler, P. P., Kalyango, Y., Paasch, M. E. (2016). Facebook use and negative body image among U.S. college women. Women \& Health, 57 (2), 1-19.

- Engeln-Maddox, R., Miller, S. A. (2008). Talking Back to the Media Ideal: The Development and Validation of the Critical Processing of Beauty Images Scale. Psychology of Women Quarterly, 32 (2), 159-171.

- Erceg Jugović, I. (2011). Nezadovoljstvo tijelom u adolescenciji. Klinička psihologija, 4 (1-2), 41-58.

- Erceg Jugović, I. (2015). Čimbenici nezadovoljstva tijelom u adolescenciji (doktorski rad). Zagreb: Filozofski fakultet.

- Fardouly, J., Diedrichs, P. C., Vartanian, L. R., Halliwell, E. (2015). Social comparisons on social media: The impact of Facebook on young women's body image concerns and mood. Body Image, 13, 38-45.

- Ferguson, B. (2005). Information Literacy: A Primer for Teachers, Librarians, and Other Informed People. Dostupno na: http:// bibliotech.us/pdfs/InfoLit.pdf. Preuzeto 10. siječnja 2018.

- Festinger, L. (1954). A Theory of Social Comparison Processes. Human Relations, 7 (1), 117-140.

- Gjylbegaj, V. (2018). Media Effects and Body Image Perceptions on Youth in UAE. International E-Journal of Advances in Social Sciences, 4 (11), 415-423.

- Golan, M., Hagay, N., Tamir, S. (2013). The Effect of „In Favor of Myself“: Preventive Program to Enhance Positive Self and Body Image among Adolescents. Plos One, 8 (11), 1-9.

- Gospodnetić, F., Morić, D. (2014.) Mladi i mediji u Hrvatskoj. Zagreb: Forum za slobodu odgoja.

- Grabe, S., Ward, L. M., Hyde, J. S. (2008). The Role of the Media in Body Image Concerns Among Women: A Meta-Analysis of Experimental and Correlational Studies. Psychological Bulletin, 134 (3), 460-476.

- Groesz, L. M., Levine, M. P., Murnen, S. K. (2002). The Effect of Experimental Presentation of Thin Media Images on Body Satisfaction: A Meta-Analytic Review. International Journal of Eating Disorders, 31 (1), 1-16.

- Grogan, S. (2006). Body Image and Health: Contemporary Perspectives. Journal of Health Psychology, 11 (1), 523-530.

- Hadžiselimović, Dž. (2004). (Video)medijska pismenost, manipulacija, ovisnost. Metodički ogledi, 11 (1), 29-40.

- Hargreaves, D. A., Tiggemann, M. (2006). Body Image is For Girls: A Qualitative Study of Boys’ Body Image. Journal of Health Psychology, 11 (4), 567-576.

- Harriger, J. A., Calogero, R. M., Witherington D. C., Smith, J. E. (2010). Body Size Stereotyping and Internalization of the Thin Ideal in Preschool Girls. Sex Roles, 63 (9-10), 609-620.

- Harrison, K., Cantor, J. (1997). The Relationship between Media Consumption and Eating Disorders. Journal of Communication, 47 (1), 40-67.

- Heinberg, L. J., Thompson, J. K. (1995). Body Image and Televised Images of Thinness and Attractiveness: A Controlled Laboratory Investigation. Journal of Social and Clinical Psychology, 14 (4), 325-338.

- Hendrickse, J., Arpan, L. M., Clayton, R. B., Ridgway, J. L. (2017). Instagram and college women’s body image: Investigating the roles of appearance-related comparisons and intrasexual competition. Computers in Human Behavior, 74, 92-100.

- Ilišin, V., Bouillet, D., Gvozdanović, A., Potočnik, D. (2013). Mladi u vremenu krize. Zagreb: Institut za društvena istraživanja i Friedrich Ebert Stiftung.

- Katzmarzyk, P. T., Davis, C. (2001). Thinness and Body Shape of Playboy Centrefolds from 1978. to 1998. International Journal of Obesity and Related Metabolic Disorders, 25, 590-592.

- Kearney, M. C. (2006). Girls Make Media. New York: Routledge.

- Kellner, D., Share, J. (2005). Toward Critical Media Literacy: Core Concepts, Debates, Organizations and Policy. Discourse: Studies in the Cultural Politics of Education, 26 (3), 369-386.

- Khan, A. N., Khalid, S., Khan, H. I., Jabeen, M. (2011). Impact of Today’s Media on University Student's Body Image in Pakistan: A Conservative, Developing Country’s Perspective. BMC Public Health, 11 (5), 379-385. 
- Kiefner-Burmeister, A. (2014). The Benefits and Trajectory of Airbrushing-Based Media Literacy Among Girls (doktorski rad). Ohio: Graduate College of Bowling Green State University.

- Kim, J. W., Chock, T. M. (2015). Body image 2.0: Associations between social grooming on Facebook and body image concerns. Computers in Human Behavior, 48, 331-339.

- Koltay, T. (2011). The Media and the Literacies: Media Literacy, Information Literacy, Digital Literacy. Media, Culture and Society, 33 (2), 211-221.

- Kuhar, M. (2005). Medijske reprezentacije tjelesnog izgleda i samopredodžba mladih. Medijska istraživanja, 11 (1), 97-112.

- Labaš, D., Marinčić, P. (2018). Mediji kao sredstvo zabave u očima djece. Medianali, 12 (15), 1-32.

- Labre, M. P., Walsh-Childers, K. (2003). Friendly Advice? Beauty Messages in Web Sites of Teen Magazines. Mass Communication and Society, 6 (4), 379-396.

- Lasić-Lazić, J., Špiranec S., Banek Zorica, M. (2012). Izgubljeni u novim obrazovnim okruženjima - pronađeni u informacijskom opismenjavanju. Medijska istraživanja, 18 (1), 125-142.

- Lawrie, Z., Sullivan, E. A., Davies, P. S., W., Hill, R. J. (2006). Media Influence on the Body Image of Children and Adolescence. Eating Disorders, 14 (1), 355-364.

- Lumb, B. A. (2006). The Effect of a Media Literacy Intervention on Female Body Image (doktorski rad). Carleton University: Ottawa, Ontario.

- Malkin, A. R., Wornian, K., Chrisler, J. C. (1999). Woman and Weight: Gendered Messages on Magazine Covers. Sex Roles, 40, 647-656.

- Mandarić, V. (2012). Novi mediji i rizično ponašanje djece i mladih. Bogoslovna smotra, 82 (1), 131-149.

- Martens, H. (2010). Evaluating Media Literacy Education: Concepts, Theories and Future Directions. Journal of Media Literacy Education, 2 (1), 1-22.

- Martínez-González, M., Gual, P., Lahortiga, F., Alonso, Y., de Irala-Estévez, J., Cervera, S. (2003). Parental factors, mass media influences, and the onset of eating disorders in a prospective population-based cohort. Pediatrics, 111 (2), 315-320.

- McCabe, M. P., Ricciardelli, L. A. (2001). Parent, peer, and media influences on body image and strategies to both increase and decrease body size among adolescent boys and girls. Adolescence, 36 (142), 225-240.

- McKnight, I. (2003). Risk Factors for the Onset of Eating Disorders in Adolescent Girls: Results of the McKnight Longitudinal Risk Factor Study. American Journal of Psychiatry, 160 (2), 248-254.

- Meier, E. P., Gray, J. (2014). Facebook Photo Activity Associated with Body Image Disturbance in Adolescent Girls. Cyberpsychology, Behavior, and Social Networking, 17 (4), 199-206.

- Miliša, Z., Šaravanja, M. (2011). Analiza medijskih sadržaja u čitankama za osnovne škole. Medianali, 5 (9), $179-196$.

- Mills, J. S., Shannon, A., Hogue, J. (2017). Beauty, Body Image and the Media, 145-157. U: Levine, M. (ur.), Perception of Beauty. London: IntechOpen.

- Miočić, B., Perinić, J. (2014). New Media Literacy Skills of Youth in Zadar. Medijska istraživanja, 20 (2), 231-253.

- Monro, F., Huon, G. (2005). Media-Portrayed Idealized Images, Body Shame and Appearance Anxiety. International Journal of Eating Disorders, 38 (1), 85-90.

- Morris, A. M., Katzman, D. K. (2003). The Impact of the Media on Eating Disorders in Children and Adolescents. Paediatrics and Child Health, 8 (5), 287-289.

- Neumark-Sztainer, D., Levine, M. P. Paxton, S. J., Smolak, L., Piran, N., Wertheim, E. H. (2006). Prevention of Body Dissatisfaction and Disordered Eating: What Next? Eating Disorders, 14 (4), 265-285.

- Pfaff-Rüdiger, S., Riesmeyer, C., Kümpel, A. (2012). Media Literacy and Developmental Tasks: A Case Study in Germany. Medijske studije, 3 (6), 42-57.

- Pokrajac-Bulian, A., Živčić-Bečirević, I., Vukmanović, S., Forbes, G. (2005). Nezadovoljstvo tjelesnim izgledom i navike hranjenja kod studentica i njihovih majki. Psihologijske teme, 14 (1), 57-70.

- Pokrajac-Bulin, A., Stubbs, S., Ambrosi-Randić, N. (2004). Različiti aspekti slike tijela i navike hranjenja u adolescenciji. Psihologijske teme, 13, 91-104.

- Pope, H. G., Olivardia, R., Gruber, A., Borowiecki, J. (1999). Evolving Ideals of Male Body Image as Seen Through Action Toys. International Journal of Eating Disorders, 26, 65-72.

- Potter, J. (2012). Medijska pismenost, Beograd: Multimedia Clio. 
- Puglia, P. R. (2017). Social Media Use and its Impact on Body Image: The Effects of Body Comparison Tendency, Motivation for Social Media Use, and Social Media Platform on Body Esteem in Young Women (doktorski rad). Chapel Hill: University of North Carolina.

- Ricciardelli, L. A., McCabe, M. P., Banfield, S. (2000). Body Image and Body Change Methods in Adolescent Boys: Role of Parents, Friends and the Media. Journal of Psychometric Research, 48, 189-197.

- Ridolfi, D. R., Myers, T. A., Crowther, J. H., Ciesla, J. A. (2011). Do Appearance Focused Cognitive Distortions Moderate the Relationship between Social Comparisons to Peers and Media Images and Body Image Disturbance? Sex Roles, 65 (7-8), 491-505.

- Roberts, D. F., Foehr, U. G., Rideout, J. V., Brodie, M. (2004). Kids and Media in America. Cambridge: Cambridge University Press.

- Roberts, D., Rideout, V., Foehr, U. (2005). Generation M: Media in the Lives of 8-18 year olds. Menlo Park, CA: Kaiser Family Foundation.

- Slater, A., Tiggemann, M., Hawkins, K., Werchon, D. (2012). Just One Click: A Content Analysis of Advertisements on Teen Web Sites. Journal of Adolescent Health, 50 (4), 339-345.

- Smith, S. L., Choueti, M., Prescott, A., Pieper, K. (2013). Gender roles and occupations: A look at character attributes and jobrelated aspirations in film and television, An Executive Report, Los Angeles, CA: Annenberg School for Communication and Journalism, University of Southern California, The Geena Davis Institute on Gender in Media.

- Spurr, S., Berry, L., Walker, K. (2013). Exploring Adolescent Views of Body Image: The Influence of the Media. Issues in Comprehensive Pediatric Nursing, 36 (1-2), 17-36.

- Stice, E., Shaw, H. (2004). Eating Disorder Prevention Programs: A Meta-Analytic Review. Psychological Bulletin, 130 (2), $206-227$.

- Stice, E., Whitenton, K. (2002). Risk Factors for Body Dissatisfaction in Adolescent Girls: A Longitudal Investigation. Developmental Psychology, 38 (5), 669-678.

- Strasburger, V. C., Jordan, A. B., Donnerstein, E. (2010). Health Effects of Media on Children and Adolescents. Pediatrics, 125 (4), 756-767.

- Striegel-Moore, R. H., Franko, D. I. (2002). Body Image Issues among Girls and Women, 183-191. U: Cash, F. T., Pruzinsky, T. (ur.), Body Image: Handbook of Theory, Research and Clinical Practice. New York: The Guilford Press.

- Tiggemann, M. (2006). The Role of Media Exposure in Adolescent Girl's Body Dissatisfaction and Drive for Thinness: Prospective Results. Journal of Social and Cognitive Psychology, 25 (5), 523-541.

- Tiggemann, M., Pickering, A. S. (1996). Role of Television in Adolescent Women's Body Dissatisfaction and Drive for Thinness. International Journal of Eating Disorders, 20 (2), 199-203.

- Tiggemann, M., Slater, A. (2013). NetGirls: The Internet, Facebook and Body Image Concern in Adolescent Girls. International Journal of Eating Disorders. 46 (6), 630-633.

- Tiggemann, M., Zaccardo, M. (2015). Exercise to be fit, not skinny“: The effect of fitspiration imagery on women’s body image. Body Image, 15, 61-67.

- van den Berg, P., Neumark-Sztainer, D., Hannan, P. J., Haines, J. (2007). Is dieting advice from magazines helpful or harmful? Five-year associations with weight-control behaviors and psychological outcomes in adolescents. Pediatrics, 119 (1), 30 -37.

- Van Vonderen, K. E., Kinnally, W. (2012). Media Effects on Body Image: Examining Media Exposure in the Broader Context of Internal and Other Social Factors. American Communication Journal, 14 (2), 41-57.

- Vidaček Hainš, V., Kirinić, V., Pletenac, K. (2007). Media Literacy as Compared to Other Elements of the Information Literacy Model. Medijska istraživanja, 13 (1), 69-85.

- Watson, R., Vaughn, L. M. (2006). Limiting the Effects of the Media on Body Image: Does the Length of a Media Literacy Intervention Make a Difference? Eating Disorders, 14 (5), 385-400.

- Yager, Z., O’Dea, J. A. (2008). Prevention Programs for Body Image and Eating Disorders on University Campuses: A Review of Large, Controlled Interventions. Health Promotion International, 23 (2), 173-189.

- Yamamiya, Y., Cash, T. F., Melnyk, S. E., Posavac, H. D., Posavac, S. S. (2005). Women’s Exposure to Thin-and-Beautiful Media Images: Body Image Effects of Media-Ideal Internalization and Impact-Reduction Interventions. Body Image, 2 (1), 74-80.

- Zgrabljić Rotar, N. (2010). Mediji - medijska pismenost, medijski sadržaji i medijski utjecaji, 9-44. U: Zgrabljić Rotar, N. (ur.), Medijska pismenost i civilno društvo, Sarajevo: Media Centar.

- Žuran, K., Ivanišin, M. (2013). Media Literacy in Times of Media Divides. Medijske studije, 4 (8), 3-16. 


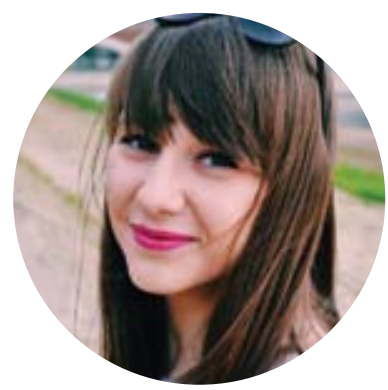

Tea Stipan

Tea Stipan rođena je u Bjelovaru 1991. godine, gdje je završila osnovnu školu i gimnaziju. Diplomirala je komunikologiju na smjeru odnosa $\mathrm{s}$ javnošću na Hrvatskim studijima 2015. godine na temu „Izloženost mladih medijskim idealima ljepote i učinak intervencije medijske pismenosti na samopredodžbu vlastitog izgleda“ te sociologiju na Filozofskom fakultetu u Zagrebu 2016. godine na temu „Osobno je političko: neokonzervativne prijetnje pravu na pobačaj $u$ Republici Hrvatskoj“. Područja znanstvenog interesa uključuju sociologiju roda, s naglaskom na reproduktivna prava žena, sociologiju medija, digitalne medije i društvene mreže, medijsku pismenost djece i mladih. Zaposlena je u Bruketa \& Žinić \& Grey te je urednica na neprofitom portalu Libela. 